UDK 528.14

\title{
GEODEZINIŲ TINKLŲ SUDARYMAS KLASIŲ PAVIDALU
}

\author{
Jonas Skeivalas \\ Geodezijos ir kadastro katedra, Vilniaus Gedimino technikos universitetas, \\ Saulètekio al. 11, LT-10223 Vilnius, Lietuva, \\ el.paštas: Jonas.Skeivalas@ap.vtu.lt
}

Lteikta 200702 05, priimta 20070629

\begin{abstract}
Santrauka. Nagrinejjama geodezinių tinklų sudarymo klasių pavidalu tikslingumas ir žemesnės klasės tinklų matavimų tikslumo priklausomybė nuo aukštesnès klasės tinklų atitinkamų parametrų tikslumo. Aukštesnès klasės tinklų parametrų klaidų ịtaka žemesnių klasių tinklų išmatuotų dydžių tikslumui analizuojama remiantis pradinių duomenų klaidų teorija. Parodyta, kad atitinkamų klasių išmatuotų dydžių klaidų tolerancijų pasikliovimo tikimybės priklauso nuo geodezinių tinklų atitinkamų dydžių standartinių nuokrypių santykio bei taikomo tolerancijų parametro $t_{\alpha}$. Pateikiamos geodezinių tinklų atitinkamų dydžių pirmosios ir antrosios rūšies klaidų pasikliovimo, atsižvelgiant i minètąsias parametrų reikšmes, tikimybès.
\end{abstract}

Reikšminiai žodžiai: tolerancijos, standartiniai nuokrypiai, pirmosios ir antrosios rūšies klaidos.

\section{Ivadas}

Geodeziniai tinklai sudaromi klasių pavidalu. Viena pagrindinių funkcinių sąlygų, taikomų aukštesnès klasės tinklams, tai patikima žemesnès klasès tinklų, jungiamu prie aukštesnès klasès tinklų, kokybès kontrolè. Geodezinių tinklų matavimuose išmatuotų dydžių tikslumui įvertinti ir matavimų rezultatams priimti arba brokuoti dažnai taikomi nesaryšiai, apskaičiuoti pagal uždarų poligonų eigas arba pagal eigas tarp aukštesnès klasès tinklo taškų. Kadangi aukštesnès klasès tinklo atitinkamų dydžių ir parametrų reikšmès turi klaidų, nes nustatytos tam tikru tikslumu, tai žemesnių klasių tinklų matavimo duomenu prièmimo arba brokavimo patikimumas priklauso nuo tam tikrų sąlygų. Aprioriškai galima tvirtinti, kad matavimo duomenu prièmimo arba brokavimo patikimumas yra didesnis tuo atveju, kai aukštesnès klasès tinklo dydžiai ir parametrai be klaidų. Aukštesnès klasès tinklo dydžiu klaidos turi tą pačią prasmę kaip ir pradinių duomenų klaidos. Todèl geodezinių tinklų, skaidomų klasėmis, analizei galima taikyti pradinių duomenų klaidų teoriją. Dėl aukštesnès klasès tinklo klaidų, taigi pradinių duomenų klaidų, įtakos tam tikra dalis žemesnès klasès tinklų geru matavimo rezultatų yra brokuojami (pirmosios rūšies klaida) ir kartu tam tikra dalis blogu rezultatų laikomi gerais (antrosios rūšies klaida). Todèl, kontroliuojant matavimo rezultatus, būtina nustatyti priimtinas pirmosios ir antrosios rūšies klaidu rizikos (tikimybès) reikšmes. Tokiai analizei atlikti remsimès teoriniais teiginiais, išdèstytais darbuose [1-3].

\section{Teorinès prielaidos}

Tolesniuose teoriniuose aiškinimuose darysime prielaida, kad geodezinių tinklų matavimo rezultatu klaidos yra atsitiktinès, ir jų skirstinys yra normalusis.

Geodezinių tinklų išmatuotų dydžių rezultatų kokybei tikrinti taikoma atitinkamų dydžių funkcinè išraiška, kurios pavidalas priklauso nuo tinklo rūšies. Pavienių dydžių matavimo klaidų ìvertinti nèra galimybès. Tuo atveju, kai išmatuotu dydžiu funkcijos yra netiesinès, jos yra linearizuojamos skleidžiant eilutemis. Matavimo rezultatų funkcijų klaidoms kontroliuoti taikoma tolerancija $d_{\varphi}$, nustatoma pagal lygybę

$$
d_{\varphi}=t_{\alpha} \sigma_{\varphi}
$$

čia $t_{\alpha}$ - parametras, kurio reikšmė priklauso nuo taikytos klaidu skirstinio funkcijos ir tikimybès $\alpha ; \sigma_{\varphi}-$ atitinkamos išmatuotų dydžių funkcijos standartinis nuokrypis.

Kontroliuojant tolerancija $d_{\varphi}$ žemesnių klasių geodezinių tinklų išmatuotų dydžių funkcijų klaidas, laikant aukštesnès klasės tinklo dydžius neklaidingais, funkcijos klaidų priimtinumo sąlyga yra nelygybė

$$
\left|\Delta_{\varphi}\right| \leq d_{\varphi},
$$

o broko požymis -

$$
\left|\Delta_{\varphi}\right|>d_{\varphi},
$$


čia $\Delta_{\varphi}$ - matavimo rezultatų funkcijos atsitiktinè klaida.

Tačiau aukštesnès klasès tinklo dydžiuose taip pat yra klaidų, jos turi ịtakos žemesnès klasès tinklų išmatuotų dydžių tikslumui. Todèl matavimo rezultatu kokybė kontroliuojama pagal nesąryši

$$
\omega=\Delta_{\varphi}+\Delta_{u},
$$

čia $\Delta_{u}$ - pradinių duomenų aukštesnès klasès tinklo atitinkamų dydžių atsitiktinè suminè klaida. Taigi matavimo klaidų pripažinimo tinkamais rezultatais požymis bus ne (2) nelygybè, o nelygybè

$$
|\omega|=\left|\Delta_{\varphi}+\Delta_{u}\right| \leq d
$$

o brokavimo požymis -

$$
|\omega|>d
$$

Šiose nelygybèse tolerancija $d$ skaičiuojama taip:

$$
d=t_{\alpha} \sigma_{\omega},
$$

čia $\sigma_{\omega}^{2}=\sigma_{\varphi}^{2}+\sigma_{u}^{2}, \sigma_{u}-$ pradiniu duomenu standartinis nuokrypis.

Tikimybė $P_{g}$ matavimų kontrolès metu gauti gerus matavimo rezultatus, taikant (2) nelygybę, apskaičiuojama taip:

$$
P_{g}=P\left(-d_{\varphi}<\Delta_{\varphi} \leq d_{\varphi}\right)=\int_{-d_{\varphi}}^{d_{\varphi}} f\left(\Delta_{\varphi}\right) d \Delta_{\varphi},
$$

čia $f\left(\Delta_{\varphi}\right)$-žemesnès klasès tinklo matavimų atsitiktinès klaidos $\Delta_{\varphi}$ normaliojo skirstinio tankio funkcija.

Tikimybė $P_{b}$ nustatyti broką yra lygi:

$$
\begin{aligned}
& P_{b}=P\left(-d_{\varphi}>\Delta_{\varphi}>d_{\varphi}\right)= \\
& \int_{-\infty}^{-d_{\varphi}} f\left(\Delta_{\varphi}\right) d \Delta_{\varphi}+\int_{d}^{\infty} f\left(\Delta_{\varphi}\right) d \Delta_{\varphi} .
\end{aligned}
$$

Tuo atveju, kai žemesnès klasès tinklas remiasi aukštesnès klasės tinklu, pastarujų lygybių realizuoti praktikoje negalima.

Nustatysime ịvykio $A_{0}$ tikimybę $P_{0}$, kad nesąryšiai $\omega$ patektų i ribinių reikšmiu sriti, apibrèžtą jų tolerancija $d$, kai žemesnès klasès tinklo matavimo rezultatų funkcijos atsitiktinès klaidos atitinka savujų toleranciju $d_{\varphi}$ sąlygas. Galime parašyti šią išraišką:

$$
P_{0}=\int_{-d_{\omega}}^{d_{\oplus}} f(\omega) d \omega=\int_{-d_{\varphi}}^{d_{\varphi}} \int_{d_{u}}^{d_{u}} f\left(\Delta_{\varphi}, \Delta_{u}\right) d \Delta_{\varphi} d \Delta_{u},
$$

čia $f\left(\Delta_{\varphi}, \Delta_{u}\right)$ - atsitiktinių klaidų sistemos, $\left(\Delta_{\varphi}, \Delta_{u}\right)-$ normaliojo skirstinio tikimybiu tankio funkcija, $d_{u}=t_{\alpha} \sigma_{u}$.

Lygybę (10) galime parašyti tokiu pavidalu [1, 3]:

$$
\begin{aligned}
& P_{0}=P\left\{(-d<\omega \leq d) \quad \mid\left(-d_{\varphi}<\Delta_{\varphi} \leq d_{\varphi}\right)\right\}= \\
& \int_{-d_{\varphi}}^{d_{\varphi}} f\left(\Delta_{\varphi}\right) d \Delta_{\varphi} \int_{-d_{u}}^{d_{u}} f\left(\Delta_{u}\right) d \Delta_{u}= \\
& \int_{-d_{\varphi}}^{d_{\varphi}} f\left(\Delta_{\varphi}\right) d \Delta_{\varphi} \int_{-d-\Delta_{\varphi}}^{d-\Delta_{\varphi}} f\left(\Delta_{u}\right) d \Delta_{u} .
\end{aligned}
$$

Pastaroji lygybė gauta remiantis žemesnès klasès tinklų klaidų $\Delta_{\varphi}$ nepriklausomumu nuo aukštesnès klasés tinklo klaidų $\Delta_{u}$.

Ši lygybė apibrěžia tikimybę, kad žemesnès klasès tinklo geri matavimų rezultatai bus pripažinti gerais.

Ivykio $A_{1}$ tikimybe $P_{1}$ nesąryšiui $\omega$ nepatekti i pasikliautinaji intervalą $(-d, d)$, esant sąlygai, kad atsitiktinè klaida $\Delta_{\varphi}$ atitiks toleranciją $d_{\varphi}$, užrašoma taikant Bayes'o teoremą [1]:

$$
\begin{aligned}
& P_{1}=P\left\{(-d>\omega>d) \mid\left(-d_{\varphi}<\Delta_{\varphi} \leq d_{\varphi}\right)\right\}= \\
& \left\{\int_{-\infty}^{-d-\Delta_{\varphi}} f\left(\Delta_{u}\right) d_{u}+\int_{d-\Delta_{\varphi}}^{\infty} f\left(\Delta_{u}\right) d \Delta_{u}\right\} \int_{-d_{\varphi}}^{d_{\varphi}} f\left(\Delta_{\varphi}\right) d \Delta_{\varphi} .
\end{aligned}
$$

Ši lygybė rodo tikimybę, kad tam tikra dalis žemesnès klasès tinklo geru matavimo rezultatų bus pripažinti blogais ir brokuojami (pirmosios rūšies klaida).

Ivykio $A_{2}$ tikimybè $P_{2}$ nesąryšiui $\omega$ patekti i pasikliautinaji intervalą $(-d, d)$, esant sąlygai, $\mathrm{kad}$ atsitiktinè klaida $\Delta_{\varphi}$ neatitiks tolerancijos $d_{\varphi}$, išreiškiama lygybe

$$
\begin{aligned}
& P_{2}=P\left\{(-d<\omega \leq d) \quad \mid\left(-d_{\varphi}>\Delta_{\varphi}>d_{\varphi}\right)\right\}= \\
& \int_{-d-\Delta_{\varphi}}^{-d-\Delta_{\varphi}} f\left(\Delta_{u}\right) d \Delta_{u}\left\{\int_{-\infty}^{-d_{\varphi}} f\left(\Delta_{u}\right) d \Delta_{u}+\int_{d}^{\infty} f\left(\Delta_{\varphi}\right) d \Delta_{\varphi}\right\} .
\end{aligned}
$$

Pastaroji lygybė apibréžia tikimybę, kad tam tikra dalis žemesnès klasès tinklo blogų matavimo rezultatų bus pripažinta gerais (antrosios rūšies klaida).

Tikimybèms $P_{0}, P_{1}$ ir $P_{2}$ skaičiuoti taikyta skaitinis integravimas esant atsitiktiniu klaiduc $\Delta_{\varphi}$ ir $\Delta_{u}$ normaliajam skirstiniui. Skaičiavimu rezultatai, kai parametro $t_{\alpha}$ ir koeficiento $k=\sigma_{\varphi} / \sigma_{u}$ reikšmés ìvairios, pateikti lentelèje procentais. Tikimybè $P_{0}$ apibrèžia tikimybę tokio ịvykio, kai tinkami žemesnès 
klasès tinklo matavimų rezultatai nebus brokuojami taikant nesąryšius $\omega$. Tikimybè $P_{1}$ - tai tinkamų matavimo rezultatu brokavimo tikimybè (pirmosios rūšies klaida), o tikimybe் $P_{2}$ - tikimybè priimti brokuotą matavimo rezultatą kaip tinkamą (antrosios rūšies klaida).

Pateiktos formulès ir skaičiavimų rezultatai rodo, kad žemesnès klasès tinklų matavimo rezultatų klaidų
$\Delta_{\varphi}$ nustatymo pagal nesąryšius $\omega$ tikimybė priklauso nuo koeficiento $k$ reikšmès bei nuo parametro $t_{\alpha}$ reikšmès, o pastaroji nuo taikomų klaidu skirstinio ir atitinkamos tikimybès, taikomos tolerancijų skaičiavimuose. Koeficientas $k$ apibrèžia žemesnès ir aukštesnès klasių tinklų išmatuotujų dydžių standartinių nuokrypiu, t. y. jų tikslumo, santyki.

Tikimybių priklausomybè nuo parametro $t_{\alpha}$ ir koeficiento $k$

\begin{tabular}{|l|l|l|l|l|l|l|l|l|l|}
\hline \multirow{2}{*}{$k$} & \multicolumn{3}{|l|}{$t_{\alpha}=1(\alpha=68,27 \%)$} & \multicolumn{3}{c|}{$t_{\alpha}=2(\alpha=95,45 \%)$} & \multicolumn{2}{l|}{$t_{\alpha}=3(\alpha=99,73 \%)$} \\
\cline { 2 - 11 } & $P_{0}$ & $P_{1}$ & $P_{2}$ & $P_{0}$ & $P_{1}$ & $P_{2}$ & $P_{0}$ & $P_{1}$ & $P_{2}$ \\
\hline 1,0 & 55,0 & 25,3 & 12,7 & 93,0 & 9,8 & 1,7 & 99,0 & 3,3 & 0,2 \\
\hline 1,5 & 60,0 & 17,1 & 8,2 & 94,0 & 6,5 & 1,4 & 99,1 & 1,1 & 0,1 \\
\hline 2,0 & 65,0 & 12,3 & 7,0 & 95,0 & 4,1 & 1,2 & 99,2 & 0,6 & 0,1 \\
\hline 2,5 & 70,0 & 9,4 & 6,0 & 96,0 & 2,9 & 1,1 & 99,3 & 0,4 & 0,1 \\
\hline 3,0 & 75,0 & 7,7 & 5,2 & 97,0 & 2,2 & 1,0 & 99,4 & 0,3 & 0,1 \\
\hline 3,5 & 80,0 & 6,5 & 4,6 & 97,5 & 1,8 & 0,9 & 99,5 & 0,2 & 0,1 \\
\hline 4,0 & 85,0 & 5,6 & 4,3 & 98,0 & 1,5 & 0,8 & 99,6 & 0,2 & 0,05 \\
\hline
\end{tabular}

\section{Išvados}

1. Žemesnès klasès tinklų, kurie remiasi aukštesnès klasès tinklu, išmatuotu dydžių klaidos priklauso nuo aukštesnès klasės tinklų tikslumo, t. y. nuo pradinių duomenų klaidų.

2. Žemesnès klasès tinklų matavimo rezultatų prièmimo arba brokavimo tikimybè priklauso nuo nusistatytosios tolerancijos $d_{\varphi}$ parametro $t_{\alpha}$ reikšmiu bei nuo koeficiento $k=\sigma_{\varphi} / \sigma_{u}$, apibrèžiančio žemesnès klasès tinklų ir pradinių duomenų klaidų standartiniu nuokrypių santyki, t. y. nuo atitinkamų tinklų tarpusavio tikslumo.

3. Optimalus matavimu variantas, kai koeficiento $k$ reikšmė yra intervale $k=3-4$, nes šiuo atveju esant $t_{\alpha}=2$ nebrokuojama $97 \%$ ar $98 \%$ geru matavimo rezultatu, o kai $t_{\alpha}=3,-99,5 \%$.

\section{Literatūra}

1. KOCH, K. R. Einführung in die Bayes-Statistik. Berlin Heidelberg, Springer-Verlag, 2000. 225 S.

2. KOCH, K. R. Räumliche Helmert-Transformation variabler Koordinaten im Gauss-Helmert und im Gauss-Markoff Model. Z. f. Vermessungswesen, 2002, No 3. Stuttgart: Verlag K. Witwer, S. 147-152.

3. SKEIVALAS, J. Treatment of correlated geodetic measurements. (Koreliuotų geodezinių matavimų rezultatu matematinis apdorojimas). Vilnius: Technika, 1995. 272 p. (in Lithuanian).

Jonas SKEIVALAS. Prof, Doctor Habil. Vilnius Gediminas Technical University. Dept of Geodesy and Cadastre, Saulettekio al. 11, LT-10223 Vilnius, Lithuania. $\mathrm{Ph}+37052744703$, Fax +370 2744705 , e-mail: jonas.skeivalas@ap.vtu.lt.

Author of two monographs and more than 130 scientific papers. Participated in many intern conferences and research visits to the Finish Geodetic Institute.

Research interests: processing of measurements with respect to tolerances, adjustment of geodetic networks. 